\title{
Pengaruh Lingkungan Terbangun terhadap Aktivitas Fisik Untuk Kesehatan Lanjut Usia
}

\author{
Petrus Natalivan Indradjati", Amalia Rahayu \\ Sekolah Arsitektur, Perencanaan dan Pengembangan Kebijakan, Institut Teknologi Bandung, Jl. Ganesa No.10, Lb. \\ Siliwangi, Kecamatan Coblong, Kota Bandung, Jawa Barat 40132, Indonesia \\ * Corresponding author: natalivan@sappk.itb.ac.id
}

Info Artikel : Diterima 26 Juni 2020 ; Disetujui 31 Maret 2021 ; Publikasi 1 Oktober 2021

Cara sitasi (Vancouver): Indradjati PN, Rahayu A. Pengaruh Lingkungan Terbangun terhadap Aktivitas Fisik Untuk Kesehatan Lanjut Usia. Jurnal Kesehatan Lingkungan Indonesia [Online]. 2021 Oct;20(2):112-119. https://doi.org/10.14710/jkli.20.2.112-119.

\begin{abstract}
ABSTRAK
Latar belakang: Semakin meningkatnya jumlah penduduk lanjut usia, maka persoalan kesehatan pada kelompok ini menjadi isu penting di masa mendatang. Salah satu yang berkontribusi pada kesehatan lanjut usia adalah aktivitas fisiknya yang dipengaruhi tidak hanya faktor personal tetapi juga oleh faktor lingkungan terbangun. Penelitian hubungan antara lingkungan terbangun dengan aktivitas fisik dan kesehatan lanjut usia banyak dilakukan, khususnya di negara maju, namun pada kondisi sosial ekonomi dan karakteristik perkotaan di Indonesia masih sangat terbatas.

Metode: Penelitian ini mengeksplorasi pengaruh lingkungan terbangun terhadap aktivitas fisik/kesehatan lanjut usia pada lima kelurahan di pusat Kota Surakarta. Faktor lingkungan terbangun mencakup aksesibilitas, kenyamanan, kejelasan orientasi, keamanan dan keselamatan. Pengumpulan data dilakukan dengan observasi dan penyebaran kuesioner pada 100 responden lanjut usia secara accidental (non-probabilistic sampling) dari jumlah populasi lanjut usia sebanyak 2417 jiwa. Analisis asosiasi dengan uji chi square dan uji somers'd untuk melihat hubungan antara aktivitas fisik dengan karakteristik personal lanjut usia dan faktor lingkungan terbangun.

Hasil: Kesehatan menjadi alasan utama usia lanjut melakukan aktivitas fisik (58\% responden). Namun tingkat aktivitas fisiknya tidak berhubungan dengan karakteristik personal seperti jenis kelamin, pendidikan, dan penyakit tidak menular yang diderita (nilai signifikansi $>0.05$ ). Faktor lingkungan terbangun yang berpengaruh pada aktivitas fisik lanjut usia adalah kemudahan menyeberang (nilai signifikansi 0,000) dan keamanan jalur penyeberangan (nilai signifikansi 0,000).

Simpulan: Tidak seluruh faktor lingkungan terbangun akan mendorong lanjut usia melakukan aktivitas fisik untuk menjaga kesehatannya. Intervensi terhadap faktor keamanan dan desain penyeberangan untuk mengatasi konflik dengan kendaraan bermotor sangat penting di pusat kota.
\end{abstract}

Kata kunci: lanjut usia; aktivitas fisik; kesehatan

\section{ABSTRACT}

Title: The Influence of the Built Environment on Physical Activity for the Health of Elderly

Background: As the number of elderly people increases, health problems in this group will become an important issue in the future. One of the factors that contribute to the health of the elderly is their physical activity which is influenced not only by personal factors but also by the built environment. Research on the relationship between the built environment and physical activity and the health of the elderly have been widely carried out, especially in developed countries; but the socio-economic conditions and urban characteristics in developing countries like Indonesia are still very limited. 
Method: This research explores the influence of the built environment on the physical activity/health of the elderly in five urban villages in the center of Surakarta. Built environment factors include accessibility, level of comfort, clarity of orientation, security and safety. Data collection is carried out by observing and distributing questionnaires to 100 elderly respondents by non-probabilistic sampling from a total elderly population of 2417 people. Association analysis with the Chi-square test and Somers's test to see the relationship between physical activity and personal characteristics of the elderly and built environment factors.

Result: Staying healthy is the main reason for elderly to do physical activity (58\% of respondents). However, the level of physical activity is not related to personal characteristics such as gender, education, and noncommunicable diseases (significance value $>0.05$ ). Built environment factors that affect the physical activity of the elderly are the convenience of crossing (significance value 0.000) and the safety of the crossing (significance value 0.000).

Conclusion: Not all built environmental factors will encourage the elderly to do physical activity to maintain their health. Intervention on safety factors and crossing designs to resolve conflicts with motorized vehicles is very important in the city center.

Keywords: elderly; physical activity; health

\section{PENDAHULUAN}

Populasi dunia saat ini berada pada era penduduk menua dan diperkirakan akan terus meningkat, dimana orang berusia 65 atau lebih membentuk kelompok usia yang paling cepat berkembang di dunia. Laporan yang dikemukakan oleh United Nations juga menunjukkan bahwa pada tahun 2018, untuk pertama kalinya dalam sejarah, orang berusia 65 tahun atau lebih mempunyai jumlah lebih banyak dibandingkan jumlah anak berusia di bawah lima tahun di seluruh dunia dan diproyeksikan antara tahun 2019 hingga 2050, jumlahnya melampaui dua kali lipat perkiraan jumlah anak balita. ${ }^{(1)}$ World Health Organization (WHO) pada tahun 2018 juga menunjukkan proyeksi bahwa antara tahun 2015 hingga 2050, proporsi penduduk usia lebih dari 60 tahun akan meningkat dari $12 \%$ menjadi $22 \%$, dimana $80 \%$ lanjut usia tinggal di negara-negara berpendapatan menengah dan rendah sehingga membutuhkan perhatian lebih dari aspek layanan kesehatan dan sosial. ${ }^{(2)}$ Di Indonesia persentase usia lanjut meningkat 9,6\% (25 juta-an) meningkat dua kali lipat dari tahun 1971 hingga 2019. ${ }^{(3)}$ Perkembangan usia lanjut tersebut memberikan implikasi persoalan strategis terkait kesehatan, keselamatan, akses terhadap fasilitas, pembiayaan, dan peran lanjut usia dalam pembangunan berkelanjutan. $^{(4)}$

Lanjut usia adalah seseorang yang telah memasuki usia 60 tahun ke atas. ${ }^{(5)}$ Pengertian yang sama dikemukakan dalam Undang-undang Nomor 13 Tahun 1998 tentang Kesejahteraan Lanjut Usia. Kelompok lanjut usia mengalami proses penuaan yang ditandai dengan tubuh yang semakin rentan, dimana kemunduran fisik akan berpengaruh pada aktivitas hidup sehari-hari dan penurunan mobilitas. ${ }^{(6,7)}$ WHO telah merekomendasikan lanjut usia terlibat dalam aktivitas fisik dengan intensitas sedang, setidaknya 150 menit per minggu atau intensitas tinggi setidaknya 75 menit per minggu. Aktivitas fisik adalah gerakan tubuh yang dihasilkan oleh otot rangka yang membutuhkan pengeluaran energi. ${ }^{(8)}$

Perilaku aktivitas fisik pada lanjut usia dipengaruhi oleh empat faktor yaitu faktor personal, faktor interpersonal, faktor tingkah laku, dan faktor lingkungan. ${ }^{(9)}$ Kondisi lingkungan terbangun sangat penting dan akan berdampak pada peningkatan kualitas hidup serta kemampuan beradaptasi terhadap penuaan. Karena keterbatasan fungsional lanjut usia, atribut lingkungan harus mudah untuk dilalui, padat, dan aman..$^{(10)}$ Desain lingkungan harus mempertimbangkan kedekatan atau kemudahan akses dari dan menuju berbagai fasilitas dan moda transportasi umum, keamanan lingkungan, serta fasilitas pejalan kaki untuk mendorong pergerakan dan partisipasi sosial. Laatikainen dkk. juga menyatakan bahwa lingkungan yang ramah pejalan kaki, konektivitas, kepadatan, penggunaan lahan campuran, lingkungan hijau, dan kedekatan rumah dengan tujuan adalah karakteristik lingkungan yang penting dalam mendukung kesehatan lanjut usia. ${ }^{(1)}$ Penelitian yang dilakukan oleh Solbraa dkk. (2018) menunjukkan bahwa lingkungan yang didesain dengan kemudahan akses, menarik, dan nyaman akan mendorong aktivitas fisik lanjut usia. ${ }^{(12)}$ Penelitian ini menunjukkan bahwa lanjut usia yang tinggal di lingkungan ramah pejalan kaki, rata-rata menghabiskan waktu sekitar 50 menit/minggu lebih banyak untuk aktivitas fisik transportasi, dan memiliki aktivitas fisik sedang hingga berat sekitar 3,1 menit/hari dibandingkan dengan mereka yang tinggal di lingkungan yang kurang ramah pejalan kaki. Lingkungan yang ramah pejalan kaki dapat mendorong lanjut usia untuk melakukan aktivitas fisik.

Penelitian pengaruh lingkungan terbangun terhadap aktivitas fisik/kesehatan lanjut usia masih sangat terbatas di Indonesia. Studi komparasi terkait variasi pola aktivitas fisik yang dilakukan oleh lanjut usia masih dibutuhkan karena karakteristik kota, kondisi sosial dan ekonomi yang berbeda-beda. ${ }^{(13)}$ 


\section{MATERI DAN METODE}

Aktivitas fisik dalam penelitian ini dibatasi pada aktivitas berjalan kaki, olah raga dan bersepeda yang pada umumnya dilakukan oleh lanjut usia dalam kehidupan sehari-hari dan dipertahankan seumur hidup. ${ }^{(14,15)}$ Penelitian ini mengeksplorasi faktorfaktor yang memengaruhi aktivitas fisik lanjut usia. Lima kelurahan di pusat Kota Surakarta dipilih menjadi wilayah studi karena dianggap paling rentan untuk usia lanjut, mewakili lingkungan dengan fasilitas lengkap, saling berdekatan, keragaman guna lahan serta memiliki proporsi jumlah penduduk lanjut usia lebih banyak.

Survei data primer dilakukan dengan observasi untuk menilai tingkat keramahan lingkungan bagi lanjut usia dan penyebaran kuesioner untuk mengidentifikasi aktivitas fisik lanjut usia dan persepsi terhadap kondisi lingkungan terbangun. Pengumpulan data melalui kuesioner dilakukan dengan sampling non probabilistic, disebarkan secara accidental kepada 100 responden dari jumlah populasi lanjut usia sebanyak 2417 jiwa (Kecamatan Dalam Angka Tahun 2019 yang diterbitkan BPS Kota Surakarta). Penyebaran kuesioner dilakukan secara proporsional menurut jumlah lanjut usia pada lima kelurahan, yaitu 24 responden di Sriwedari, 23 responden di Kemlayan 18 responden di Kampung Baru, 18 responden di Keprabon dan 11 responden di Timuran.

Preferensi dan penilaian tingkat keramahan lingkungan terbangun pada lanjut usia dilakukan dengan evaluasi semu berdasarkan kriteria dan indikator yang dihasilkan dari kajian literatur (Tabel 1). Analisis asosiasi chi-square dan analisis uji sommers'd digunakan untuk melihat hubungan antara karakteristik lanjut usia dan persepsi keramahan lingkungan dengan aktivitas fisik. Hipotesa yang digunakan adalah:

- H0 : Tidak terdapat hubungan antara keaktifan lanjut usia dengan karakteristik lanjut usia/persepsi keramahan lingkungan

- H1 : Terdapat hubungan antara keaktifan lanjut usia dengan karakteristik lanjut usia/persepsi keramahan lingkungan.

Pada uji chi square, apabila nilai signifikansinya (Asymp. Sig. (2 sided)) $<0.05$ maka H0 ditolak dan H1 diterima, dan sebaliknya jika nilai signifikansinya (Asymp. Sig. (2 sided)) $>0.05$. Dalam uji Somers'd, apabila nilai signifikansinya (approx sig.) $<0.05$ maka H0 ditolak dan H1 diterima, dan jika sebaliknya $\mathrm{H} 0$ diterima dan $\mathrm{H} 1$ ditolak, apabila nilai signifikansinya (approx. sig.) $>0.05$. Nilai koefisien Somers'd yang positif menunjukkan hubungan yang searah, sedangkan nilai koefisien yang negatif menunjukkan hubungan yang tidak searah. Keeratan hubungan dilihat melalui besarnya nilai koefisien, dengan kategori sebagai berikut:

$$
\begin{aligned}
& -0,00-0,199: \text { sangat lemah } \\
& -0,20-0,399: \text { lemah } \\
& -0,40-0,599: \text { sedang } \\
& -0,60-0,799: \text { kuat } \\
& -0,80-1,00: \text { sangat kuat. }
\end{aligned}
$$

\section{Tabel 1. Kriteria dan Indikator Evaluasi Tingkat Keramahan Lingkungan untuk Usia Lanjut}

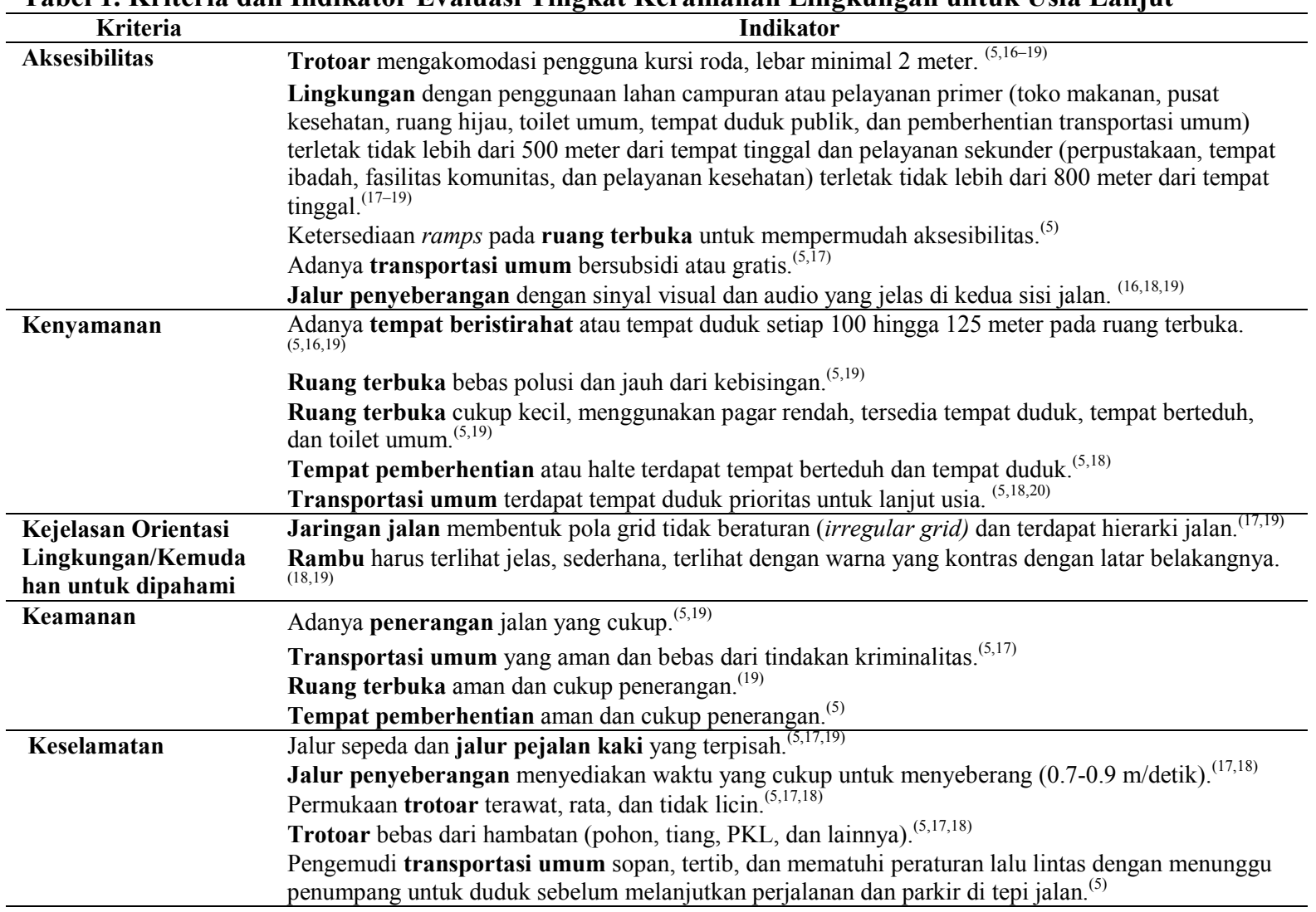


HASIL DAN PEMBAHASAN

Tingkat Keramahan Lingkungan Terbangun, Karakteristik dan Factor Pendorong Aktivitas Fisik Lanjut Usia

Persepsi responden lanjut usia terkait keramahan lingkungan terbangun menunjukkan bahwa, kondisi lingkungan terbangun cukup baik dan sangat baik atau ramah untuk melakukan aktivitas fisik (Gambar 1). Merujuk pada hasil penelitian Hirsch dkk., (2017) dan Laatikainen dkk., (2018), bahwa kondisi lingkungan dianggap memiliki pengaruh yang kuat pada aktivitas fisik lanjut usia dan memengaruhi kapasitas mereka untuk menjaga kemandirian dan Kesehatan ${ }^{(21,22)}$, maka persepsi ini menunjukkan bahwa tidak ada kendala bagi usia lanjut dalam melakukan aktivitas fisik dan lingkungan tempat tinggal mereka cukup mendukung aktivitas fisik untuk kesehatan. Demikian juga tidak ada faktor penghambat aktivitas fisik seperti yang dikemukakan oleh Vine dkk. (2012), yang menunjukkan bahwa ketergantungan pada kendaraan bermotor, kepentingan pejalan kaki dan pengendara sepeda yang bersaing pada jalur bersama dan masalah yang terkait dengan sistem transit, transportasi umum, dan infrastruktur pejalan kaki muncul sebagai hambatan utama bagi lanjut usia yang bepergian dengan berjalan kaki. ${ }^{(21)}$

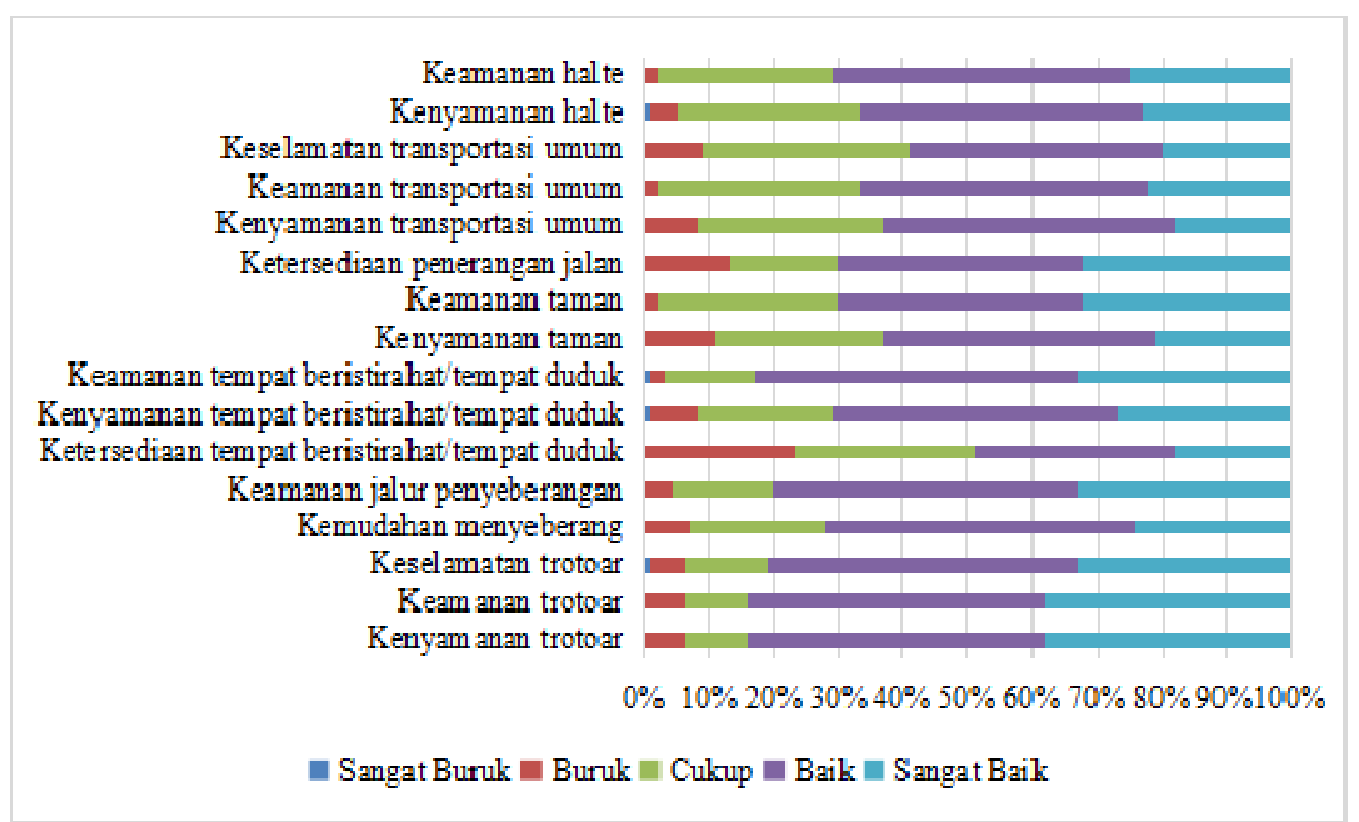

Gambar 1 Persepsi Responden Usia Lanjut terkait Tingkat Keramahan Lingkungan

Dalam konteks tingkat keramahan lingkungan terbangun seperti tersebut di atas, bahwa sebagian besar lanjut usia sangat aktif beraktivitas fisik (Gambar 2). Dikatakan sangat aktif apabila aktivitas fisik dilakukan setiap hari; aktif, apabila aktivitas fisik dilakukan 2-4 kali/minggu; cukup aktif, apabila aktivitas fisik dilakukan seminggu sekali; kurang aktif, apabila aktivitas fisik dilakukan setidaknya sebulan sekali; dan, tidak aktif, apabila tidak melakukan aktivitas fisik.

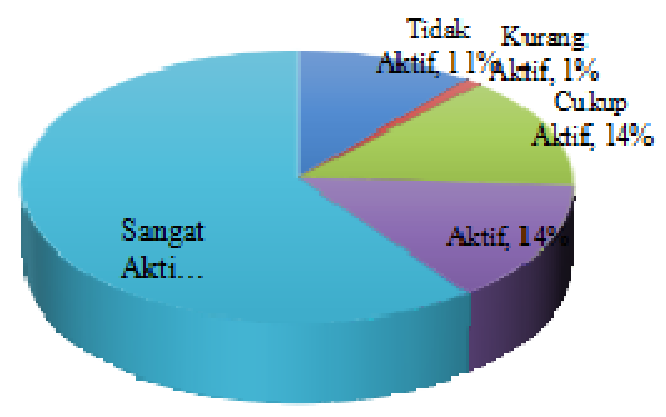

Gambar 2. Keaktifan Aktivitas Fisik Lanjut Usia

Responden lebih banyak menghabiskan waktu untuk berolahraga dengan jarak rata-rata 1.800 meter dengan durasi berjalan rata-rata 30 menit sesuai dengan rekomendasi WHO yaitu 150 menit per minggu. ${ }^{(8)}$ Sementara frekuensi aktivitas fisik dengan bersepeda, didominasi untuk tujuan bekerja. Responden bersepeda dengan jarak rata-rata 4.600 meter dengan durasi bersepeda rata-rata 32 menit. Radius perjalanan dengan sepeda ini masih berkisar di pusat kota.

Aktivitas fisik lanjut usia didasari oleh berbagai motif. Motif yang paling memengaruhi aktivitas fisik adalah alasan kesehatan (didiagnosa penyakit yang berelasi dengan aktivitas fisik seperti Penyakit Tidak Menular/PTM), untuk bekerja dan berbelanja. Sementara yang tergolong tidak aktif, disebabkan oleh rasa malas dalam diri lanjut usia dan kurangnya kesadaran pentingnya aktivitas fisik (Gambar 3). Motif ini menunjukkan ada nya unsur 'keterpaksaan' dalam melakukan aktivitas fisik. Kondisi ini menunjukkan adanya faktor lain di luar faktor 
lingkungan terbangun yang mempengaruhi pola aktivitas fisik. Demikian juga, dominannya pola aktivitas fisik untuk bekerja dengan sepeda menunjukkan adanya pola yang sama. Aktivitas fisik dengan sepeda tidak ada kaitannya dengan upaya menjaga kondisi tubuh dan tingkat keramahan lingkungan. Aktivitas fisik yang dilakukan untuk bekerja, atau aktivitas dasar cenderung tidak sensitif terhadap kondisi lingkungan terbangun.

Pola aktivitas fisik lanjut usia ini menunjukkan kebenaran adanya perdebatan teoritis terkait hubungan antara kualitas lingkungan terbangun dengan mobilitas penghuni khususnya aktivitas fisik dan kesehatan masyarakat sebagaimana dikemukakan oleh Fisher dkk., (2004), Rosso dkk., (2011), Van Cauwenberg dkk., (2011), dan Sun dkk., (2013). ${ }^{(23-26)}$ Informasi ini penting untuk ekplorasi lebih lanjut dan memastikan seberapa besar faktor tingkat keramahan suatu lingkungan tempat tinggal terhadap dorongan lanjut usia melakukan aktivitas fisik.

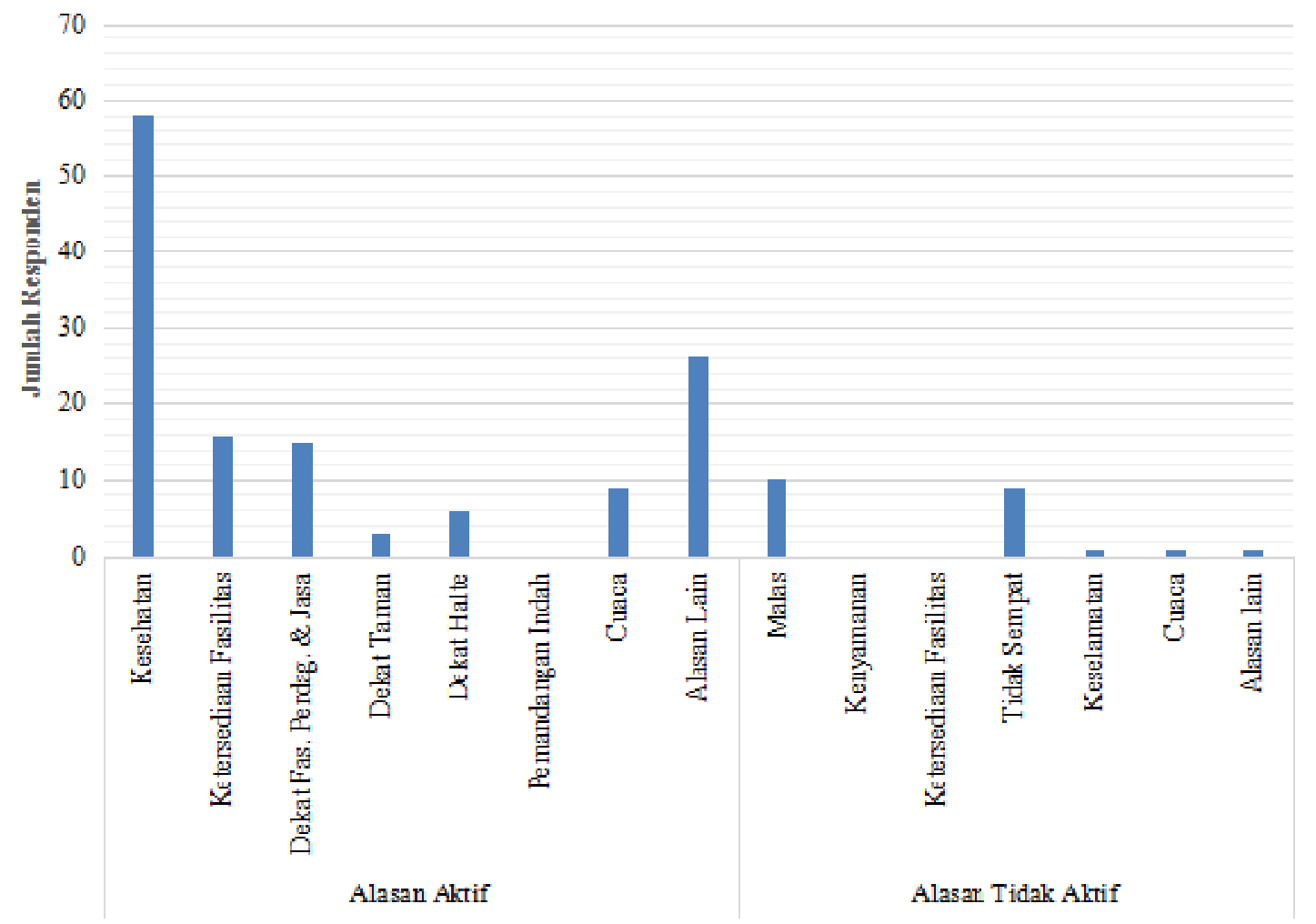

Gambar 3. Alasan Keaktifan dan Ketidakaktifan Melakukan aktivitas Fisik

Hubungan Lingkungan Terbangun, Aktivitas Fisik dan Kesehatan Lanjut Usia

Faktor pendorong aktivitas fisik lanjut usia dilihat dari dua faktor, yaitu faktor personal, dan faktor lingkungan. Faktor personal mencakup jenis kelamin, usia, status tempat tinggal, latar belakang pendidikan, mata pencaharian, pendapatan rata-rata serta latar belakang ada tidaknya penyakit tidak menular yang mempunyai kaitan aktivitas fisik. Berdasarkan faktor personal ini dan hubungannya dengan aktivitas fisik yang dilakukan menunjukkan nilai signifikansi sebagaimana ditunjukkan dalam Tabel 2. Nilai signifikansi $>0.05$ menunjukkan bahwa tingkat keaktifan lanjut usia dalam melakukan aktivitas fisik tidak ada hubungannya dengan karakteristik personal tersebut di atas. Wawancara yang dilakukan untuk mengkonfirmasi hasil ini menunjukkan adanya indikasi bahwa faktor yang memengaruhi lanjut usia untuk aktif atau tidak aktif dalam beraktivitas adalah keinginan mereka untuk hidup sehat. Hasil ini menunjukkan terdapat ketidak konsistenan antara faktor personal terkait latar belakang penyakit tidak menular (PTM) yang diderita oleh responden lanjut usia yang tidak mempunyai hubungan dengan aktivitas fisik dengan alasan kesehatan dalam melakukan aktivitas fisik. Kesadaran untuk hidup sehat menyebabkan lanjut usia tetap aktif beraktivitas fisik, seperti berjalan kaki dan bersepeda.

\section{Tabel 2. Analisis Asosiasi Karakteristik Lanjut} Usia dengan Tingkat Keaktifan Fisik

\begin{tabular}{clcc}
\hline No & \multicolumn{1}{c}{ Variabel } & Uji & Nilai Sig. \\
\hline 1 & Jenis Kelamin & Chi Square & 0,752 \\
2 & Usia & Somers'd & 0,666 \\
3 & Status tinggal & Chi Square & 0,329 \\
4 & Pendidikan terakhir & Somers'd & 0,597 \\
5 & Mata pencaharian & Chi Square & 0,505 \\
6 & Pendapatan rata-rata & Somers'd & 0,853 \\
7 & Penyakit Tidak Menular & Chi Square & 0,988 \\
& (PTM) & &
\end{tabular}

Hubungan antara persepsi tingkat keramahan lingkungan untuk lanjut usia dan aktivitas fisik dilakukan untuk mencari tahu ada tidaknya hubungan 
diantara keduanya. Dalam studi ini tingkat keaktifan fisik lanjut usia dianalisis asosiasinya dengan variabelvariabel terkait keramahan lingkungan. Tabel 3 berikut merupakan hasil dari analisis asosiasi korelatif dengan uji somers'd.

Tabel 3. Analisis Asosiasi Tingkat Keaktifan Fisik dengan Persepsi Keramahan Lingkungan

\begin{tabular}{lccc}
\hline \multicolumn{1}{c}{ Variabel } & Nilai & $\begin{array}{c}\text { Nilai Signifikansi } \\
\text { (Approx. Sig.) }\end{array}$ & Keberadaan hubungan \\
\hline Kenyamanan trotoar & 0,054 & 0,504 & Tidak ada hubungan \\
Keamanan trotoar & 0,113 & 0,175 & Tidak ada hubungan \\
Keselamatan trotoar & 0,110 & 0,181 & Tidak ada hubungan \\
Kemudahan menyeberang & $\underline{\mathbf{0 , 3 0 4}}$ & $\underline{\mathbf{0 , 0 0 0}}$ & Ada hubungan \\
Keamanan jalur penyeberangan & $\underline{\mathbf{0 , 2 8 7}}$ & $\underline{\mathbf{0 , 0 0 0}}$ & Ada hubungan \\
Ketersediaan tempat duduk & 0,068 & 0,408 & Tidak ada hubungan \\
Kenyamanan tempat duduk & 0,043 & 0,583 & Tidak ada hubungan \\
Keamanan tempat duduk & 0,043 & 0,583 & Tidak ada hubungan \\
Kenyamanan taman & -0.023 & 0,783 & Tidak ada hubungan \\
Keamanan taman & 0.36 & 0,681 & Tidak ada hubungan \\
Ketersediaan penerangan jalan & 0.109 & 0,193 & Tidak ada hubungan \\
Kenyamanan transportasi umum & 0.069 & 0,421 & Tidak ada hubungan \\
Keamanan transportasi umum & 0.131 & 0,124 & Tidak ada hubungan \\
Keselamatan transportasi umum & 0.075 & 0,361 & Tidak ada hubungan \\
Kenyamanan halte & 0.061 & 0,464 & Tidak ada hubungan \\
Keamanan halte & 0.144 & 0,097 & Tidak ada hubungan \\
\hline
\end{tabular}

Nilai signifikansi tabel di atas menunjukkan bahwa yang memiliki hubungan antara tingkat keaktifan dalam beraktivitas fisik dengan lingkungan terbangun hanya variabel kemudahan menyeberang dan keamanan jalur penyeberangan (nilai signifikansi $<0.05$ ). Meskipun terdapat hubungan yang signifikan, namun keeratan hubungan ini masuk kategori lemah (nilai antara 0,20-0,399). Nilai koefisien yang positif menunjukkan hubungan kedua variabel searah, dimana semakin mudah dan aman dalam menyeberang, maka keaktifan lansia dalam melakukan aktivitas fisik akan semakin meningkat.

Analisis asosiasi di atas menunjukkan bahwa hubungan antara lingkungan terbangun dan aktivitas fisik tidak sepenuhnya selaras dengan temuan penelitian lainnya. Hal ini menunjukkan bahwa faktor lingkungan terbangun tidak cukup berpengaruh terhadap keaktifan lanjut usia dalam beraktivitas fisik. Hasil ini juga menunjukkan pola yang sama, bahwa tidak ada perbedaan signifikan aktivitas fisik dari dua karakter lingkungan perumahan dari penelitian Indradjati. ${ }^{(27)}$ Namun, penelitian ini menunjukkan aspek keselamatan dan keamanan berjalan kaki cukup berpengaruh sebagaimana hasil penelitian Booth dkk., (2000). ${ }^{(28)}$ Hasil penelitian ini memperkuat hasil penelitian sebelumnya yang menunjukkan bahwa faktor kesehatan mempunyai pengaruh signifikan terhadap aktivitas fisik; variabel personal seperti tinggal bersama keluarga atau hidup sendiri juga tidak mempunyai pengaruh terhadap pola aktivitas fisik. ${ }^{(29,30)}$ Penelitian ini mempunyai hasil yang berbeda dengan penelitian Poggio (2016), terkait pengaruh gender dan status sosial ekonomi yang tidak berpengaruh pada keaktifan aktivitas fisik yang dilakukan lanjut usia. ${ }^{(31)}$

\section{SIMPULAN}

Penelitian ini menyimpulkan tiga hal. Pertama Karakteristik personal lanjut usia tidak mempengaruhi aktivitas fisik yang dilakukan lanjut usia, meskipun mempunyai masalah kesehatan akibat kurangnya aktivitas fisik. Kedua, faktor lingkungan terbangun tidak sepenuhnya mempengaruhi dorongan lanjut usia beraktivitas fisik, hanya aspek kemudahan dan keamanan menyeberang yang berpengaruh. Ketiga, meskipun alasan kesehatan menjadi motif utama dalam beraktivitas fisik, namun kurangnya kesadaran terhadap pentingnya aktivitas fisik untuk kesehatan menjadi faktor penghambat dalam beraktivitas fisik. Upaya meningkatkan aktivitas fisik lanjut usia diperlukan tidak hanya intervensi terhadap lingkungan terbangun, tetapi juga dibutuhkan peningkatan kesadaran dan rekayasa sosial terkait pentingnya aktivitas fisik untuk kesehatan lanjut usia.

\section{DAFTAR PUSTAKA}

1. Department of Economic and Social Affairs Population Division. World Population Prospects 2019. New York: United Nations; 2019.

2. World Health Organization. Ageing and Health [Internet]. World Health Organization. 2018 [cited 2020 Jun 19]. Available from: https:/www.who.int/news-room/factsheets/detail/ageing-and-health.

3. Badan Pusat Statistik Kota Surakarta. Statistik Penduduk Lanjut Usia 2019. Surakarta: Badan Pusat Statistik Kota Surakarta; 2019.

4. United Nations Development Program, HelpAge International, AARP. Ageing, Older Persons and 
the 2030 Agenda for Sustainable Development. New York: United Nations Development Programme; 2017.

5. WHO - World Health Organization. Global Agefriendly Cities: A Guide. France; 2007.

6. Fatmah. Gizi Usia Lanjut. Jakarta: Erlangga; 2010.

7. Stoneham J, Thoday PR. Landscape Design for Elderly and Disabled People. Abardeen: Garden Art Press; 1996.

8. World Health Organization Europe. Physical Activity and Health in Europe: Evidence for Action. Cavill N, Kahlmeier S, Racioppi F, editors. Copenhagen; 2006.

9. Manz K, Mensink GBM, Jordan S, Schienkiewitz A, Krug S, Finger JD. Predictors of Physical Activity Among Older Adults in Germany: A Nationwide Cohort Study. BMJ Open. 2018;8(e021940):110.https://doi.org/10.1136/bmjopen-2018021940

10. Zang P, Xue CQL, Lu Y, Tu K. Neighbourhood Adaptability for Hong Kong's Ageing Population. Urban Des Int. 2018;24(3):187205.https://doi.org/10.1057/s41289-018-0074-z

11. Laatikainen TE, Haybatollahi M, Kyttä M. Environmental, Individual and Personal Goal Influences on Older Adults' Walking in the Helsinki Metropolitan Area. Int J Environ Res Public Health. 2018;16(1):119.https://doi.org/10.3390/ijerph16010058

12. Solbraa AK, Anderssen SA, Holme IM, Kolle E, Hansen BH, Ashe MC. The Built Environment Correlates of Objectively Measured Physical Activity in Norwegian Adults: A Cross-sectional Study. J Sport Heal Sci. 2018;7(1):1926.https://doi.org/10.1016/j.jshs.2017.11.002

13. Sanders GJ, Roe B, Knowles ZR, Kaehne A, Fairclough SJ. Using Formative Research with Older Adults to Inform a Community Physical Activity Programme: Get Healthy, Get Active. Prim Heal Care Res Dev. 2019;20(e60):110.https://doi.org/10.1017/S1463423618000373

14. Chudyk AM, McKay HA, Winters M, SimsGould J, Ashe MC. Neighborhood Walkability, Physical Activity, and Walking for Transportation: A Cross-sectional Study of Older Adults Living on Low Income. BMC Geriatr. 2017; 17(82):1-

14.https://doi.org/10.1186/s12877-017-0469-5

15. Huang R, Moudon A V, Zhou C, Saelens BE. Higher Residential and Employment Densities are Associated with more Objectively Measured Walking in the Home Neighborhood. J Transp Heal. $2019 ; 12: 142$ 51.https://doi.org/10.1016/j.jth.2018.12.002

16. United Nations Centre for Human Settlements (Habitat). Improving the Quality of Life of the Elderly and Disabled in Human Settlements. Nairobi: United Nations Habitat; 1993.

17. Eryl JS. Ageing and the City: Making Urban Spaces Work for Older People. London:
HelpAge International; 2016.

18. Pemerintah Republik Indonesia. Peraturan Pemerintah Republik Indonesia Nomor 43 Tahun 2004 tentang Pelaksanaan Upaya Peningkatan Kesejahteraan Sosial Lanjut Usia. Indonesia; 2004.

19. Burton E, Mitchell L. Inclusive Urban Design: Streets for Life. Oxford: Architectural Press is an Imprint of Elsevier; 2006.https://doi.org/10.4324/9780080456454

20. Pemerintah Republik Indonesia. Undang-undang Republik Indonesia Nomor 1 Tahun 2011 tentang Perumahan dan Kawasan Permukiman. Indonesia; 2011.

21. Vine D, Buys L, Aird R. Experiences of Neighbourhood Walkability Among Older Australians Living in High Density Inner-City Areas. Plan Theory Pract. 2012;13(3):42144.https://doi.org/10.1080/14649357.2012.69667 5.

22. Hirsch JA, Winters M, Clarke PJ, Ste-Marie N, McKay HA. The Influence of Walkability on Broader Mobility for Canadian Middle Aged and Older adults: An Examination of Walk ScoreTM and the Mobility Over Varied Environments Scale (MOVES). Prev Med (Baltim). 2017;95:S60-

7.https://doi.org/10.1016/j.ypmed.2016.09.036

23. Fisher KJ, Li F, Michael Y, Cleveland M. Neighborhood-Level Influences on Physical Activity among Older Adults: A Multilevel Analysis. J Aging Phys Act. 2004;12(1):4563.https://doi.org/10.1123/japa.12.1.45

24. Rosso AL, Auchincloss AH, Michael YL. The Urban Built Environment and Mobility in Older Adults: A Comprehensive Review. J Aging Res. 2011;1-10.https://doi.org/10.4061/2011/816106

25. Van Cauwenberg J, De Bourdeaudhuij I, De Meester F, Van Dyck D, Salmon J, Clarys P, et al. Relationship Between the Physical Environment and Physical Activity in Older Adults: A Systematic Review. Heal Place. 2011;17(2):458-

69.https://doi.org/10.1016/j.healthplace.2010.11. 010

26. Sun F, Norman IJ, While AE. Physical Activity in Older People: a Systematic Review. BMC Public Health. 2013;13(449):1-17. https://doi.org/10.1186/1471-2458-13-449

27. Indradjati $\mathrm{P}$, Elfrida $\mathrm{M}$. Pengaruh Tingkat Keramahan Lingkungan Perumahan Bagi Pejajan Kaki Terhadap Aktivitas Fisik dan Kesehatan Masyarakat (Kasus: Perumahan Margahayu Raya, Bandung). J Permukim. 2020 May 30;15(1):10-

8.https://doi.org/10.31815/jp.2020.15.10-18

28. Booth ML, Owen N, Bauman A, Clavisi O, Leslie E. Social-cognitive and Perceived Environment Influences Associated with Physical Activity in Older Australians. Prev Med (Baltim). 2000;31(1):1522.https://doi.org/10.1006/pmed.2000.0661 
29. Silva A, Teixeira B, Guimarães C, Pereira P, Fernandes R, Mendes F. Physical Activity And Subjective Well-Being In The Elderly. In: The European Proceeding of Social \& Behavioural Sciences. Future Academy; 2018. p. 16572.https://doi.org/10.15405/epsbs.2018.11.18

30. McPhee JS, French DP, Jackson D, Nazroo J, Pendleton N, Degens H. Physical Activity in Older Age: Perspectives for Healthy Ageing and Frailty. Biogerontology. 2016;17(3):56780.https://doi.org/10.1007/s10522-016-9641-0

31. Poggio R, Serón P, Calandrelli M, Ponzo J, Mores N, Matta MG, et al. Prevalence, Patterns, and Correlates of Physical Activity among the Adult Population in Latin America: CrossSectional Results from the CESCAS i Study. Glob Heart. 2016;11(1):818.https://doi.org/10.1016/j.gheart.2015.12.013. 